\title{
Highlight report: hepatotoxicity prediction with Hep3B cells
}

\author{
Seddik Hammad ${ }^{1,2} \cdot$ Tarek Ellethy $^{3} \cdot$ Amnah Othman $^{4} \cdot$ Hassan Y. A. H. Mahmoud ${ }^{5}$
}

Received: 4 June 2018 / Accepted: 6 June 2018 / Published online: 11 June 2018

(c) Springer-Verlag GmbH Germany, part of Springer Nature 2018

Recently, Yu et al. (2018) have contributed a study with 3D-cultivated Hep3B cells tested with 22 model compounds. $\mathrm{LC}_{50}$ values were compared to rat $\mathrm{LD}_{50}$ values and human $C_{\max }$ values. At a first glance, one may ask, whether it is really justified to introduce another liver tumor cell line besides the already well-established HepG2 and HepaRG cells. However, the obtained $\mathrm{LC}_{50}$ values were remarkably low. For example, acetaminophen resulted in an $\mathrm{LC}_{50}$ of $300 \mu \mathrm{M}$, which is lower compared to many previously reported cell systems, such as HepG2. Finally, a remarkably good overall predictively of human hepatotoxicity was obtained. Currently, human hepatocytes are still considered a gold standard for in vitro testing of human hepatotoxicity (Pfeiffer et al. 2015; Leist et al. 2017; Grinberg et al. 2014; Ghallab 2017; Hammad and Ahmed 2014; Hammad et al. 2015). Moreover, hepatotoxicity represents a complex process that may involve interaction of several cell types (Jansen et al. 2017; Vartak et al. 2016; Albrecht 2017; Schenk et al. 2017). If the high predictively of the Hep3Bbased test system (Yu et al. 2018) would be confirmed by further compounds, it might indeed facilitate prediction of hepatotoxicity. However, whether prediction of idiosyncratic hepatotoxicity will be possible based on these still remains to be shown.

Seddik Hammad

seddik.hammad@vet.svu.edu.eg

1 Department of Forensic Medicine and Toxicology, Faculty of Veterinary Medicine, South Valley University, Qena, Egypt

2 Molecular Hepatology Section, Department of Medicine II, Medical Faculty Mannheim, Heidelberg University, 68167 Mannheim, Germany

3 Department of Radiotherapy and Nuclear Medicine, South Egypt Cancer Institute, Assiut University, Assiut, Egypt

4 Leibniz Institut für Analytische Wissenschaften-ISAS e.V., Dortmund, Germany

5 Division of Infectious Diseases, Animal Medicine Department, Faculty of Veterinary Medicine, South Valley University, Qena 83523, Egypt

\section{Compliance with ethical standards}

Conflict of interest The author declares that he has no conflict of interest.

\section{References}

Albrecht W (2017) Highlight report: prediction of drug induced liver injury (DILI) with human hepatocytes in vitro. Arch Toxicol 91(12):4021-4022. https://doi.org/10.1007/s00204-017-2132-5

Ghallab A (2017) Highlight report: Monitoring cytochrome P450 activities in living hepatocytes. EXCLI J 16:1330-1331. https:// doi.org/10.17179/excli2017-1039 (eCollection 2017, no abstract available)

Grinberg M, Stöber RM, Edlund K et al (2014) Toxicogenomics directory of chemically exposed human hepatocytes. Arch Toxicol 88(12):2261-2287. https://doi.org/10.1007/s00204-014-1400-x

Hammad S, Ahmed H (2014) Biomarker: the universe of chemically induced gene expression alterations in human hepatocyte. EXCLI J 13:1275-1277 (eCollection 2014, no abstract available)

Hammad S, Abdel-Wareth AAA, El-Sayed YS (2015) In vitro-in vivo correlation: Hepatotoxicity testings. JEAAS 1(3):384-387

Jansen PL, Ghallab A, Vartak N, Reif R, Schaap FG, Hampe J, Hengstler JG (2017) The ascending pathophysiology of cholestatic liver disease. Hepatology 65(2):722-738. https://doi.org/10.1002/ hep.28965 (review)

Leist M, Ghallab A, Graepel R et al (2017) Adverse outcome pathways: opportunities, limitations and open questions. Arch Toxicol 91(11):3477-3505

Pfeiffer E, Kegel V, Zeilinger K, Hengstler JG, Nüssler AK, Seehofer D, Damm G (2015) Featured article: Isolation, characterization, and cultivation of human hepatocytes and non-parenchymal liver cells. Exp Biol Med (Maywood) 240(5):645-656

Schenk A, Ghallab A, Hofmann U et al (2017) Physiologically-based modelling in mice suggests an aggravated loss of clearance capacity after toxic liver damage. Sci Rep 7(1):6224. https://doi. org/10.1038/s41598-017-04574-Z

Vartak N, Damle-Vartak A, Richter B, Dirsch O, Dahmen U, Hammad S, Hengstler JG (2016) Cholestasis-induced adaptive remodeling of interlobular bile ducts. Hepatology 63(3):951-964

Yu KN, Nadanaciva S, Rana P, Lee DW, Ku B, Roth AD, Dordick JS, Will Y, Lee MY (2018) Prediction of metabolism-induced hepatotoxicity on three-dimensional hepatic cell culture and enzyme microarrays. Arch Toxicol 92(3):1295-1310. https://doi. org/10.1007/s00204-017-2126-3 